\title{
FURTHER NOTES ON THE VASCULA FLORA OF THE HASBALA LAKE REGION, SASKATCHEWAN
}

\section{B. DE VRIES, Fort Qu'Appelle Herbarium, Fort Qu'Appelle, Saskatchewan}

The purpose of this paper is to document (1) the addition of 18 taxa to the vascular flora of the Hasbala Lake region in northeastern Saskatchewan, (2) the range extensions of four taxa, and (3) the addition of one taxon to the flora of Saskatchewan.

Earlier botanical collections in the vicinity of Hasbala Lake were made by J. W. Tyrrell ${ }^{10}$ and G. Scotter. ${ }^{789}$ A more recent detailed study of the plant species, topography and plant communities was made by Argus. ${ }^{1}$

Our field party visited Hasbala Lake in 1973, a region lying well within the subarctic section of northeastern Saskatchewan. Our survey was designed to cover as much terrain as time allowed with the objective of discovering as many unusual plants as possible.

All specimens collected have been identified by the author, and a complete set of plants deposited in the Fort Qu'Appelle Herbarium. Except for the Monocotyledoneae, the nomenclature followed is that of Boivin. ${ }^{2}$

\section{FIRST RECORDS FOR THE HASBALA LAKE REGION}

Carex supina Willd. Ssp. spaniocarpa (Stead.) Hult. 9085-73. Only as a pioneer on sandy gravel slope of esker. Previously collected from Warren Lake $^{1}$ and Lake Athabasca. ${ }^{5}$

Eriophorum vaginatum L. Ssp. spissum (Fern.) Hult. 9044-73. In wet depression on Sphagnum with $E$. vaginatum in Picea mariana muskeg. This is the first report of the subspecies for northeastern Saskatchewan. The species was previously reported by Argus. ${ }^{1}$

Populus tremuloides Michx. 914573. Known only from margin of Carex meadow in a depression at base o esker as stunted individuals. shoots were vegetative. The spe was previously collected at Wa Lake. $^{1}$

Betula occidentalis Hooker var. cidentalis. 9036-73, 9064-73. frequent as a small tree (3-4 m) sandy esker in Picea mariana - lic association and rare on sandy shore. First recorded for Patte Lake. $^{1}$

Betula papyrifera Marsh papyrifera.9140-73,9000Collected from sandy slope of ar ker and in Picea mariana - fea moss wood.

Urtica dioica L. var. procera (MI Wedd. 9127-73. Rare, known from base of sheltered slope of $e$ near wet Carex fen under Pop balsamifera. A northern extensio range of this subarctic Amer species, previously known from a in southern and cen Saskatchewan.

Rumex fennicus Murb. 912 Rare and occurring as a few dividuals at margin of wet Cares near base of sheltered slope of e This record is a marked northwar tension of this introduced Euro species frequently recorded in sc central regions of Saskatchewan collecting site and the previous show signs of human disturban one time.

Anemone multifida Poi sanguinea (Pursh) Fern. 9096-73. Seen only once on dry lichen co slope of dry depression betwee ker ridges. This is the first reco this form for northeas. Saskatchewan. The species previously collected by Argus. ${ }^{1}$ 
Ranunculus gmelinii DC. 9076-73. re. Observed only once partly suberged in a shallow pool in wet Picea ariana muskeg.

Ranunculus lapponicus L. 9071-73. are. Known only from Hylocomium lendens mat in wet Picea mariana uskeg. Known from Patterson Lake a similar habitat. ${ }^{7}$

Arabis lyrata L. 9097-73. Seen only dry lichen covered slope of dry pression between esker ridges.

Cardamine pratensis L. var. gustifolia Hooker. 9087-73. Rare. illected only once from the moist bulder field in association with Par- ssia palustris var. tenuis and tragalus alpinus. A southward exnsion of the range of this arcticrcumpolar species.

Geum allepicum Jacq. 9095-73. re. Collected once from a grassy immock in Carex meadow. A rthward extension of the skatchewan range of this subarcticmperare American species, eviously known from south-central gions of the province.

Viola adunca SM. 9041-73. Seen ily once as a few scattered inviduals on a dried-out hummock in y lichen covered depression with warf stands of Picea mariana tween esker ridges.

Cornus canadensis. L. var. dutillyi ep.) Boivin. 9030-73. Rare in a Picea ariana muskeg among the species. is is the first report of the variety om northeastern Saskatchewan. The ecies was reported by Argus. ${ }^{1}$

Pinguicula villosa L. 9072-73. Rare. en only once on wet Sphagnum immock in Picea mariana muskeg. arctic-subarctic circumpolar ecies represented in this general gion by a collection from Lake habasca. ${ }^{5}$

Arnica alpina (L.) Olin var. unvensis Boivin. 9148-73. Known only pm exposed upper ridge of esker on ineral soil. A subarctic American ecies previously collected from ke Athabasca. ${ }^{3}$
Senecio paucifloris Pursh. 9025-73. Seen only on the moist boulder field as rare individuals in shallow depression with Carex scirpoidea. Apparently new to the flora of Saskatchewan but not unexpected in view of its occurrence in northern Manitoba and Alberta. ${ }^{24}$ It is principally a subarcticalpine species favouring calcareous meadows.

\section{SECOND RECORDS FOR THE HASBALA LAKE REGION}

Two of the taxa collected were previously reported from this region by Argus as new to the flora of Saskatchewan. They are -

1) Salix arctophylla Cockerell. 905073, 9062-73, 9093-73. Infrequent on wet gravels of drainage way near Quillwort Lake and seen in wet Picea mariana muskeg. Common on the boulder field with Vaccinium uliginosum L. var. uliginosum.

2) Salix reticulatal. 9066-73, 9080-73, 9098-73. Rare in Picea mariana mixed woods and frequently carpeting wettish open subarctic habitats in Picea mariana muskeg. Common on the moist boulder field.

\section{COMMENTS}

It appears that four of the taxa which Argus recorded only for the Patterson-Warren Lakes region have now been found at Hasbala Lake and that 14 taxa collected at Hasbala Lake were not recorded by Argus for the Patterson-Hasbala Lakes.

Argus recorded 12 taxa for Hasbala Lake as belonging to the articsubarctic element ( 18 for the region as a whole). ${ }^{1}$ In addition, four of the taxa reported in this paper bring the revised total of 16 for Hasbala Lake (18 for the region). This element comprises $8.1 \%$ of the overall total for Hasbala Lake, compared to $8.3 \%$ for the region as a whole.

The presence of a significant arcticsubarctic element in the flora of northeastern Saskatchewan is not surprising, since the study area is part of 
the northwestern transitional section of Rowe $^{6}$ with close proximity of open subarctic woodlands with mixed forest-tundra vegetation.

\section{SUMMARY}

Fourteen taxa are added to the vascular flora of the PattersonHasbala Lakes region in northeastern Saskatchewan, thereby raising the total to 127. Eighteen taxa, including two subspecies, five varieties and one form, are added to Hasbala Lake, thus making a total of 197. One species is reported as new to Saskatchewan.

A reinterpretation of the vascular flora of Hasbala Lake reveals that 16, or $8.1 \%(18$, or $8.3 \%$ for PattersonHasbala Lakes) of the taxa belong to the arctic-subarctic element.

\section{ACKNOWLEDGEMENTS}

The author is indebted to his field companion Ron Hooper, field entomologist for the Saskatchewan Museum of Natural History and Mr. William Richards, Regional Field Supervisor, Department of Northern Saskatchewan, La Ronge, for their kind cooperation and assistance, without which this investigation would not have been possible.

'ARGUS, G. W. 1966. Botanical investigations in northeastern Saskatchewan: the subarctic Patterson-Hasbala Lakes region. Canadian Field Naturalist, 80 : 119-143.

${ }^{2}$ BOIVIN, B. 1967. Flora of the Prairie Pro- vinces, a handbook to the flora of $t$ provinces of Manitoba, Saskatchewa Alberta, Parts I, II, III. Provancheria Memoires de l'Herbier Louis Mari Faculte d'Agriculture, Universi Laval, and Department of Agricultur Ottawa.

${ }^{3}$ BREITUNG, A. J. 1957. Annotated cat logue of the vascular flora of Saska chewan. American Midland Natural 58: 1-72.

${ }^{4}$ MOSS, E. H. 1959 . Flora of Alber University of Toronto Press, $546 \mathrm{pp}$

${ }^{5}$ RAUP, H. 1936. Phytogeographic studi in the Athabasca-Great Slave La region. 1. Catalogue of the vascu plants. Journal Arnold Arboretum, 180-315.

${ }^{6}$ ROWE, J. S. 1959. Forest regions Canada. Canada Department Northern Affairs and Natural $R$ sources. Forestry Branch Bulletin 12 1-71.

${ }^{7}$ SCOTTER, G. 1961. Botanical collectic in the Black Lake region of northe Saskatchewan, 1960. Blue Jay, 23-33.

${ }^{8}$ SCOTTER, G. 1964. Effect of forest $\mathrm{fi}$ on the winter range of barren-grou caribou in northern Saskatchew Canadian Wildlife Service Mana: ment Bulletin, Series 1, 18: 1-109.

${ }^{9}$ SCOTTER, G. 1965. A plant collect from the Cochrane River region northwestern Manitoba. Blue Jay, 96-100.

${ }^{10}$ TYRRELL, J. B. 1897. Report on Doobal Kazan and Ferguson Rivers and northwest coast of Hudson Geological Survey of Canada, Ann Report, 9, part F: 5-218.

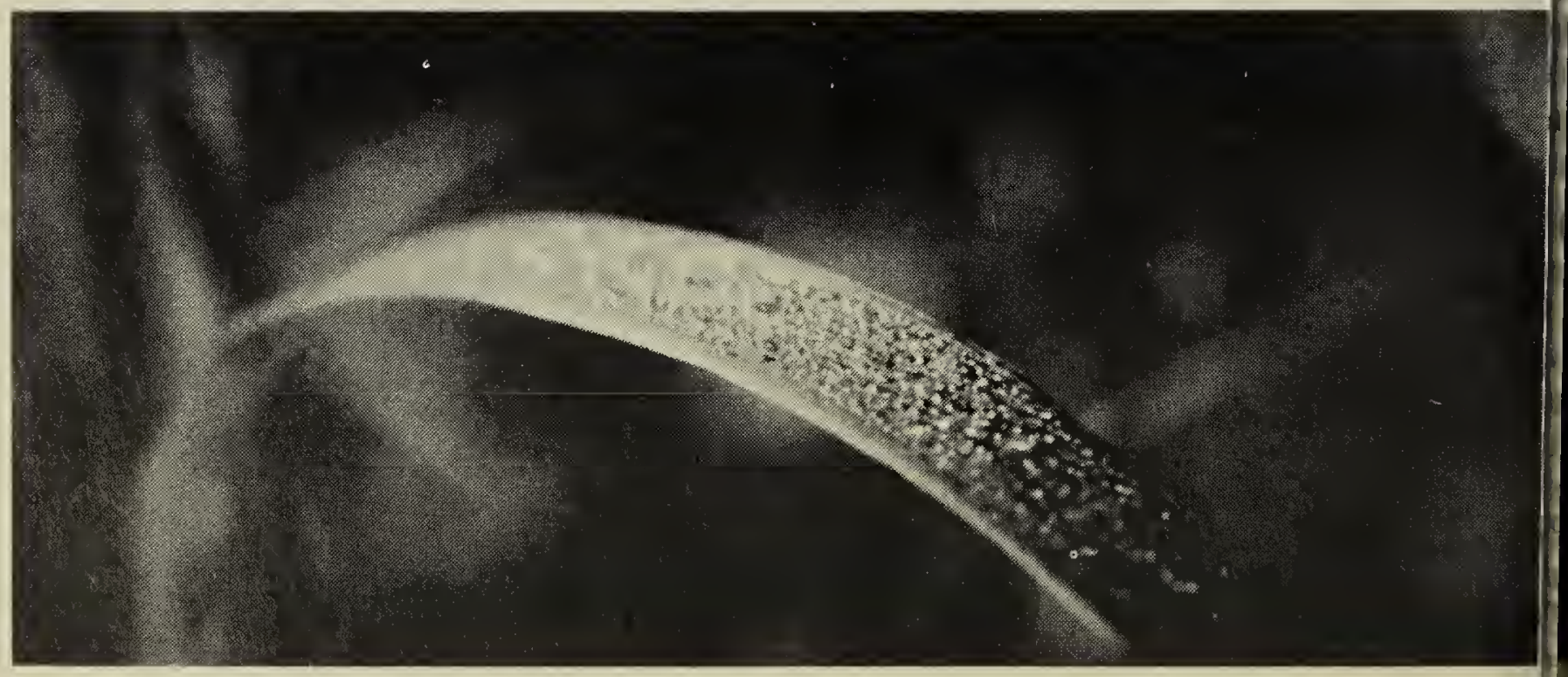

